\title{
Protection conferred on mice by combinations of monoclonal antibodies directed against outer-membrane proteins or smooth lipopolysaccharide of Brucella
}

\author{
I. JACQUES, A. CLOECKAERT**, J. N. LIMET* and G. DUBRAY†
}

Institut National de la Recherche Agronomique, Laboratoire de Pathologie Infectieuse et Immunologie, 37380 Nouzilly, France and *Unité d'Immunologie et de Microbiologie, Faculté Universitaire Notre-Dame de la paix, 61 rue de Bruxelles, 5000 Namur, Belgium

\begin{abstract}
Summary. The effect of monoclonal antibodies (MAbs) injected alone or in combination on brucella splenic infection in CD-1 mice was tested 7 and 21 days after a challenge with virulent Brucella abortus 544. Passive immunisation of mice with anti-25-27-kDa MAb alone, or mixed with protective anti-16.5 and anti-36-38-kDa MAbs, or with MAbs of the same specificity which were previously demonstrated to have no activity on CD-1 mice, produced a significant reduction of spleen counts of $B$. abortus $(\mathrm{p}<0.01)$. Other combinations of MAbs did not reduce splenic infection in comparison with the untreated control group. BALB/c mice were used to test the possible interference of the immune response of $C D-1$ mice against $\mathrm{MAbs}$ that were produced in BALB/c mice. No reduction of splenic infection was shown with anti-25-27- or -36-38-kDa MAbs, whereas anti-lipopolysaccharide (LPS) MAb which was produced in CBA mice was effective. Combination of anti-protein MAbs with the anti-LPS $M A b$ produced only the effect of the anti-LPS MAb at 7 and 21 days after challenge.
\end{abstract}

\section{Introduction}

Brucella spp. are gram-negative facultative intracellular bacteria that cause acute and chronic infection in man and animals. Protective immunity to brucellosis, as studied in the mouse model, can be transferred from donor to recipient mice by either immune serum or T-cells. ${ }^{1-3} \mathrm{~T}$-cell dependent immunity has been considered, since the work of Mackaness, ${ }^{4}$ to be the main mechanism of immune protection. However, passive transfer of monoclonal antibodies (MAbs) directed against outer-membrane proteins (OMPs) ${ }^{5}$ or smooth lipopolysaccharide (S-LPS) of Brucella ${ }^{6-9}$ confers some immunity to brucella infection in mice. We demonstrated that three MAbs directed against the 16.5-, 25-27- and 36-38-kDa OMPs reduced significantly the colonisation of the spleen at 7 days after challenge. ${ }^{5}$ Immunity conferred by anti-S-LPS MAbs of $\mathrm{A}$ or $\mathrm{M}$ specificity is in relation to the A or M S-LPS specificity expressed by the challenge strain. Nevertheless, the protection conferred by MAbs directed against OMPs, although statistically significant, was quite low compared with that conferred by the S-LPS $\mathrm{MAb}$. For this reason, we investigated the synergic action of mixtures of MAbs against several epitopes of one OMP, or against epitopes on several OMPs on infection in CD-1 mice, and the effect of MAbs against OMPs and S-LPS on infection in BALB/c mice. As most anti-OMP MAbs were obtained from BALB/c mice, the strain of mice could influence the protective response and this possibility was examined.

\section{Materials and methods}

\section{Bacterial strain}

B. abortus strain 544 , used as challenge strain, was from the culture collection held at INRA-Nouzilly. Purity and phase were checked by standard procedures. ${ }^{10}$ Cloned smooth colonies were transferred on to Blood Agar Base (BAB; Difco) slants for $24 \mathrm{~h}$. Brucella cells were then harvested in a sterile buffered saline solution (BSS; $\mathrm{NaCl} 8.5 \mathrm{~g}, \quad \mathrm{~K}_{2} \mathrm{HPO}_{4} 2 \mathrm{~g}$, $\mathrm{KH}_{2} \mathrm{PO}_{4} 1 \mathrm{~g}$, distilled water $1000 \mathrm{ml}, \mathrm{pH} 6.85$ ) and adjusted photometrically at $600 \mathrm{~nm}$ to the required concentration (optical density $=0.165$ for $10^{9} \mathrm{cfu} / \mathrm{ml}$ for 1-cm light path) and injected into mice as indicated for each experiment.

\section{Monoclonal antibodies (MAbs)}

MAbs were produced as described previously. ${ }^{5}$ They are listed in tables I and II. MAbs were used at a final dilution of 1 in 5, except for the anti S-LPS MAb of A specificity (B66/04F09) which was diluted 1 in 200 (minimal effective dose determined by Limet et al. ${ }^{7}$ ).

\section{Protection of mice}

Mice were acclimatised for 1 week before use, and 
randomly allocated to experimental groups 5 days before immunisation. Each experiment included two controls - the anti-LPS of A specificity MAb (B66/ 04F09) as positive control and BSS as negative control.

Experiment $A$. The synergic activity of MAbs directed against OMPs was tested on groups of 12 outbred CD-1, 5-week-old female mice (Charles River, Elbeuf, France). The combinations of MAbs used are given in table I. MAbs found previously to decrease brucella colonisation of spleen ${ }^{5}$ were injected alone: A66/05H01/E09 (anti-16-5-kDa OMP), A19/12B10/ F04 (anti-25-27-kDa OMP) and A63/04D11/G01 (anti-36-38-kDa OMP). MAbs (0.1 ml final volume) diluted in BSS, and BSS alone (control), were injected subcutaneously 1 day before challenge. Mice were challenged intravenously with $0.2 \mathrm{ml}$ of a suspension containing $5 \cdot 3 \log _{10}$ cfu of $B$. abortus 544 .

Experiment $B$. Groups of 18 5-week-old female BALB/c mice (Iffa-Credo, L'Arbresle, France) were used to test the effect of the combination of MAbs directed against OMP and the MAb directed against the S-LPS (A) on the protection against B. abortus 544 . Mice were given $4.4 \log _{10}$ cfu of this strain by intravenous injection 1 day after immunisation with MAbs.

Six mice from each group were killed at stated times (experiment A, days 7 and 21 ; experiment B, days 7, 21 and 49) and their spleens were removed. The number of $B$. abortus organisms in each spleen were counted by grinding, diluting and spreading on BAB. ${ }^{11,12}$ The number of $\mathrm{cfu}$ of $B$. abortus/spleen (x) was expressed as $\mathrm{y}=\log \mathrm{x}$. This last transformation normalises the distribution of individual counts, required for variance analysis..$^{13}$ Mean and SD of transformed values were then calculated. The results were evaluated by analysis of variance of all effects and interactions. ${ }^{14}$

\section{Results}

\section{Reduction of splenic infection in CD-1 mice by mixtures of anti-OMP MAbs}

The results of these experiments are shown in table I. Anti-25-27-kDa MAb (A19/12B10/F04) injected alone decreased splenic infection $(\mathrm{p}<0.05)$ in day 7 after challenge with virulent $B$. abortus, whereas anti16-5-kDa MAb (A66/05H01/E09) reduced splenic infection on day 21 after challenge only $(\mathrm{p}<0.05)$. Anti-36-38-kDa MAb (A63/04D11/G01) did not decrease splenic colonisation at either stage. The injection of these three MAbs in combination was very efficient at protecting mice, as well as the combination of MAb anti-25-27-kDa with other MAbs of the same specificity $(p<0.01)$. However, the difference between reduction of spleen counts by these combinations and by the anti-25-27-kDa MAb alone was not significant.

Table I. Protective activity of anti-OMP MAbs against B. abortus 544 (S)

\begin{tabular}{|c|c|c|c|c|c|}
\hline \multirow{2}{*}{ Clone } & \multirow{2}{*}{ MAb specificity } & \multirow{2}{*}{ Protection* } & \multirow{2}{*}{ Isotype } & \multicolumn{2}{|c|}{$\begin{array}{l}\text { Mean (SD) } \log _{10} \text { Brucella cfu } \\
\text { at days post-challenge }\end{array}$} \\
\hline & & & & 7 & 21 \\
\hline A66/05H01/E09 & $\begin{array}{l}\text { Control (saline) } \\
16.5 \mathrm{kDa}\end{array}$ & $\overline{+}$ & $\underset{\operatorname{Ig} \ddot{G} 2 \mathrm{a}}{\ldots}$ & $\begin{array}{l}6.07(0.21) \\
5.88(0.41)\end{array}$ & $\begin{array}{l}4 \cdot 60(0 \cdot 29) \\
4 \cdot 10(0 \cdot 41) \dagger\end{array}$ \\
\hline A19/12B10/F04 & $25-27 \mathrm{kDa}$ & + & IgG1 & $5.52(0.25) \dagger$ & $4.28(0.43)$ \\
\hline A63/04D11/G01 & $36-38 \mathrm{kDa}$ & + & IgG2a & $6.13(0.44)$ & $4 \cdot 48(0.28)$ \\
\hline $\begin{array}{l}\text { A66/05H01/E09 } \\
\text { A19/12B10/F04 } \\
\text { A63/04D11/G01 }\end{array}$ & $\begin{array}{r}16 \cdot 5 \mathrm{kDa} \\
25-27 \mathrm{kDa} \\
36-38 \mathrm{kDa}\end{array}$ & $\begin{array}{l}+ \\
+ \\
+\end{array}$ & $\left.\begin{array}{l}\text { IgG2a } \\
\text { IgG1 } \\
\text { IgG2a }\end{array}\right]$ & $5.37(0.05) \ddagger$ & $4 \cdot 23(0 \cdot 28)$ \\
\hline $\left.\begin{array}{l}\mathrm{A} 19 / 12 \mathrm{~B} 10 / \mathrm{F} 04 \\
\mathrm{~A} 66 / 01 \mathrm{C} 06 / \mathrm{E} 01 \\
\mathrm{~A} 68 / 04 \mathrm{~B} 10 / \mathrm{F} 05 \\
\mathrm{~A} 68 / 07 \mathrm{D} 11 / \mathrm{B} 03 \\
\mathrm{~A} 18 / 13 \mathrm{D} 02 / \mathrm{F} 05\end{array}\right]$ & $25-27 \mathrm{kDa}$ & $\begin{array}{l}+ \\
- \\
- \\
-\end{array}$ & $\left.\begin{array}{l}\text { IgG1 } \\
\text { IgG2b } \\
\text { IgG2a } \\
\text { IgG2a } \\
\text { IgG1 }\end{array}\right]$ & $5.35(0.24) \ddagger$ & $4.48(0.41)$ \\
\hline $\left.\begin{array}{l}\mathrm{A} 66 / 01 \mathrm{C} 06 / \mathrm{E} 01 \\
\mathrm{~A} 68 / 04 \mathrm{~B} 10 / \mathrm{F} 05 \\
\mathrm{~A} 68 / 07 \mathrm{D} 11 / \mathrm{B} 03 \\
\mathrm{~A} 18 / 13 \mathrm{D} 02 / \mathrm{F} 05\end{array}\right]$ & $25-27 \mathrm{kDa}$ & $\begin{array}{l}- \\
- \\
- \\
-\end{array}$ & $\left.\begin{array}{l}\text { IgG2b } \\
\text { IgG2a } \\
\text { IgG2a } \\
\text { IgG1 }\end{array}\right]$ & $5.83(0.28)$ & $4 \cdot 61(0.43)$ \\
\hline $\left.\begin{array}{c}\mathrm{A} 66 / 04 \mathrm{E} 03 / \mathrm{B} 07 \\
\mathrm{~A} 66 / 04 \mathrm{E} 05 / \mathrm{E} 09 \\
\mathrm{~A} 68 / 04 \mathrm{G} 01 / \mathrm{C} 06 \\
\mathrm{~A} 68 / 29 \mathrm{E} 03 / \mathrm{C} 10\end{array}\right]$ & $16.5 \mathrm{kDa}$ & $\begin{array}{l}- \\
- \\
- \\
-\end{array}$ & $\left.\begin{array}{l}\operatorname{IgG} 2 b \\
\operatorname{IgG} 2 a \\
\operatorname{IgG} 2 a \\
\text { IgG2a }\end{array}\right]$ & $5.75(0.33)$ & $4.42(0.34)$ \\
\hline $\left.\begin{array}{l}\mathrm{A} 68 / 07 \mathrm{G} 11 / \mathrm{C} 10 \\
\mathrm{~A} 68 / 08 \mathrm{E} 07 / \mathrm{B} 11 \\
\mathrm{~A} 63 / 04 \mathrm{~F} 07 / \mathrm{E} 03 \\
\mathrm{~A} 68 / 25 \mathrm{G} 05 / \mathrm{A} 05 \\
\mathrm{~A} 68 / 25 \mathrm{H} 10 / \mathrm{A} 05\end{array}\right]$ & $\begin{array}{r}10 \mathrm{kDa} \\
36-38 \mathrm{kDa} \\
19 \mathrm{kDa}\end{array}$ & $\begin{array}{l}- \\
- \\
- \\
-\end{array}$ & $\left.\begin{array}{l}\operatorname{IgG} 2 a \\
\operatorname{IgG} 2 a \\
\operatorname{IgM} \\
\operatorname{IgG} 2 a \\
\text { IgG2a }\end{array}\right]$ & $6.09(0.30)$ & $4 \cdot 18(0.47) \dagger$ \\
\hline B66/04F09 & S-LPS (A) & + & $\operatorname{IgG} 2 \mathrm{a}$ & $5 \cdot 13(0 \cdot 18) \ddagger$ & $3.90(0.41) \ddagger$ \\
\hline
\end{tabular}

* Protection observed by Cloeckaert et al. ${ }^{5}$

$\dagger \mathrm{p}<0.05, \ddagger \mathrm{p}<0.01$, in comparisons with untreated control group according to analysis of variance 
Table II. Protective activity of anti-OMP MAbs alone or in combination with the anti-LPS MAb against splenic infection with $B$. abortus 544

\begin{tabular}{|c|c|c|c|c|}
\hline \multirow{2}{*}{$\begin{array}{l}\text { Treatment } \\
\text { (clone) }\end{array}$} & \multirow{2}{*}{ Isotype } & \multicolumn{3}{|c|}{ Mean (SD) $\log _{10}$ Brucella cfu, at days post-challenge } \\
\hline & & 7 & 21 & 49 \\
\hline Control (BSS) & & $6 \cdot 12(0.06)$ & $7.78(0.03)$ & $6.54(0.23)$ \\
\hline Anti-LPS (B66/04FO9) & IgG2a & $5 \cdot 14(0.09)$ & $6 \cdot 17(0.41)$ & $6.83(0.23)$ \\
\hline $\begin{array}{l}\text { Anti-25-kDa OMP (1) } \\
(\mathrm{A} 19 / 12 \mathrm{~B} 10 / \mathrm{F} 04)\end{array}$ & IgG1 & $5.97(0.09)$ & $7.60(0.04)$ & $6 \cdot 11(0 \cdot 15)$ \\
\hline $\begin{array}{l}\text { Anti-25-kDa OMP (2) } \\
\text { (A18/13D02/F05) }\end{array}$ & IgG1 & $6.24(0 \cdot 10)$ & $7.74(0.08)$ & $6 \cdot 28(0 \cdot 18)$ \\
\hline $\begin{array}{l}\text { Anti-36-kDa OMP (1) } \\
\text { (A63/04D11/G01) }\end{array}$ & IgG2a & $6.29(0.08)$ & $7.67(0.06)$ & $6.33(0.07)$ \\
\hline $\begin{array}{l}\text { Anti-36-kDa OMP (2) } \\
\text { (A68/25G05A05) }\end{array}$ & $\operatorname{IgG} 2 \mathrm{a}$ & $6.11(0.06)$ & $7.67(0.07)$ & $6.53(0.35)$ \\
\hline Anti-25-27-kDa OMP (1)+anti LPS & $\operatorname{IgG} 1+\operatorname{IgG} 2 \mathrm{a}$ & $5 \cdot 19(0.04)$ & $5 \cdot 51(0 \cdot 39)$ & $6.30(0.42)$ \\
\hline Anti-25-kDa OMP (2) + anti LPS & $\operatorname{IgG} 1+\operatorname{IgG} 2 \mathrm{a}$ & $5.34(0.08)$ & $5.49(0.49)$ & $6.78(0.18)$ \\
\hline Anti-36-38-kDa OMP (1)+anti LPS & $\operatorname{IgG} 2 \mathrm{a}+\operatorname{IgG} 2 \mathrm{a}$ & $4.97(0.05)$ & $6.42(0.08)$ & $7 \cdot 19(0.23)$ \\
\hline Anti-36-kDa OMP (2) + anti LPS & $\operatorname{IgG} 2 a+\operatorname{IgG} 2 a$ & $5.05(0.04)$ & $5.64(0.27)$ & $6.76(0.09)$ \\
\hline
\end{tabular}

(1), (2), different MAbs of the same specificity.

Other combinations of MAbs failed to decrease splenic colonisation of CD-1 mice, except the combination of anti-10-, anti-19- and anti-36-38-kDa on day 21 after challenge. Control (BSS and anti-LPS MAb) results were as expected; anti-LPS MAb conferred protection at both times $(\mathrm{p}<0.01)$, BSS had no effect.

\section{Reduction of splenic infection in $B A L B / c$ mice by anti-OMP and by anti-OMP and anti-LPS MAbs}

Determination of equivalent challenge dose. For a Brucella strain, the time course of splenic infection depends on its virulence and on the resistance of the mice. To compare the efficacy of various MAbs, the challenge dose was adjusted to give a similar splenic infection in BALB/c mice as in CD-1 mice, at least 7 days after challenge. The level of splenic infection in $\mathrm{BALB} / \mathrm{c}$ mice 7 days after injection of various doses of

Table III. Statistical analysis of experiment B

\begin{tabular}{|c|c|c|}
\hline Treatment comparison* & Error: MS $\dagger$ & $\mathbf{F}$ \\
\hline \multicolumn{3}{|l|}{ On day 7} \\
\hline Control vs anti-LPS & 0.025 & $115 \cdot 6 \ddagger$ \\
\hline Control vs anti-OMP & 0.025 & 0.202 \\
\hline Control vs mixtures & 0.025 & $203 \cdot 6 \ddagger$ \\
\hline \multicolumn{3}{|l|}{ Interactions } \\
\hline $\begin{array}{l}\text { anti-LPS } \times \text { anti-25-27-kDa OMP } \\
\text { anti-LPS } \times \text { anti-36-38-kDa OMP }\end{array}$ & $\begin{array}{l}0.025 \\
0.025\end{array}$ & $\begin{array}{l}0 \cdot 12 \\
3 \cdot 50\end{array}$ \\
\hline \multicolumn{3}{|l|}{ On day 21} \\
\hline Control vs anti-LPS & 0.382 & $20 \cdot 3 \ddagger$ \\
\hline Control vs anti-OMP & $0 \cdot 382$ & 0.017 \\
\hline Control vs mixtures & $0 \cdot 382$ & $51 \cdot 05_{+}^{+}$ \\
\hline \multicolumn{3}{|l|}{ Interactions } \\
\hline anti-LPS $\times$ anti-25-27-kDa OMP & $0 \cdot 382$ & $2 \cdot 60$ \\
\hline anti-LPS $\times$ anti-36-38-kDa OMP & 0.382 & 0.008 \\
\hline \multicolumn{3}{|l|}{ On day 49} \\
\hline Control vs anti-LPS & $0 \cdot 293$ & 0.84 \\
\hline Control vs anti-OMP & $0 \cdot 293$ & 0.77 \\
\hline Control vs mixtures & $0 \cdot 293$ & 0.65 \\
\hline
\end{tabular}

* d.f. $=1$ for treatment comparison.

$\dagger$ Mean square, d.f. $=50$.

$\ddagger \mathrm{p}<0.01$.
$B$. abortus 544 was determined. At that time, mean $B$. abortus $\log _{10}$ cfu of control CD-1 mice was nearly 6 , with a challenge dose of $5.3 \log _{10} \mathrm{cfu}$. This count was produced in BALB/c mice by $4.4 \log _{10}$ cfu of the same strain.

\section{Reduction of splenic infection in $B A L B / c$ mice by mixtures of anti-OMP and anti-LPS MAbs}

Individual anti-OMP MAbs injected alone, irrespective of specificity and isotype, did not produce any reduction of splenic infection (tables II and III). Controls (BSS and anti-LPS MAb) were as expected: the anti-LPS MAb showed the usual level of protection $(5 \cdot 14)$ observed in CD-1 mice, 7 days after challenge; 21 days after challenge, the level of infection in the control group (BSS) increased to $7.78 \log _{10}$ cfu (table II). Nevertheless, anti-LPS MAb was still effective ( $p<0.01$; table III) at this time whereas on day 49 , it was not. The combination of anti-OMP MAb with the anti-LPS MAb produced significant reduction of splenic counts $(p<0.01)$ on days 7 and 21 after challenge (table III). On day 49 after challenge, no reduction of splenic infection was found, whatever the treatment administered to mice (table III).

\section{Discussion}

In previous studies, we have shown that MAbs directed against LPS A or $M$ antigens ${ }^{6,7}$ and three MAbs directed against $\mathrm{OMPs}^{5}$ are able to significantly reduce splenic infection in CD-1 mice resulting from a challenge with $B$. abortus strain 544 . We have extended this observation in two ways. Firstly, we tested whether synergic action of mixtures of anti-OMP MAbs of the same specificity or of several specificities could improve reduction of spleen colonisation in CD-1 mice. Secondly, we tested whether anti-OMP MAbs would improve the reduction of spleen colonisation when 
injected with the anti-LPS MAb in BALB/c mice Immunising with anti-25-27-kDa MAb (A19/12B10/ F04) alone $e^{5}$ or with MAbs of other specificities decreased spleen counts significantly. The combination of anti-25-27-kDa MAb (A19/12B10/F04) with anti-16.5 MAb (A66/05H01/E09) and anti-36-38$\mathrm{kDa} \mathrm{MAb}$ (A63/04G11/G01) or with the other MAbs of $25-27-\mathrm{kDa}$ specificity, reduced splenic infection significantly when compared with unprotected control mice $(p<0.01)$. These results showed that a combination of MAbs did not inhibit the activity of anti25-27-kDa MAb (A19/12B10/F04), even if the other MAbs in combination were not effective themselves; protection was not potentiated either. Synergic activity of MAbs was shown by Svennerholm et al..$^{15}$

A combination of MAbs directed against several epitopes of colonisation factor antigens enhanced protection against enterotoxigenic Escherichia coli experimental infection. However, the effect observed was primarily an antitoxic effect, whereas in experimental brucellosis, the effect was a decrease of splenic infection. Two MAbs-A66/05H01/E09 (anti-16.5$\mathrm{kDa}$ OMP) and A63/04D11/G01 (anti-36-38-kDa OMP) - that previously reduced splenic colonisation in CD-1 mice ${ }^{5}$ were no longer protective. This could be ascribed to the statistical distribution and to individual receptivity of the animals.

To test the interference of an eventual immune response of CD-1 mice against MAbs produced in $B A L B / c$, the second experiment was performed with the $\mathrm{BALB} / \mathrm{c}$ mice as subjects. This did not improve the reduction of splenic infection in mice treated with antiOMP MAb, whereas the anti-LPS MAb reduced splenic colonisation as effectively as in CD-1 mice. Thus, mixing anti-OMP MAbs with the anti-LPS $\mathrm{MAb}$ gave a result similar to the effect of the anti-LPS
$\mathrm{MAb}$ alone. This also means that the binding of the anti-LPS MAb was not affected by anti-OMP MAbs.

The failure to observe a protective effect in BALB/c mice 49 days after challenge with anti-LPS MAb is in accord with the results of Phillips et al. ${ }^{8}$ who observed an increase in splenic colonisation 8 weeks after immunisation with MAbs directed against the Opolysaccharide of the LPS. The increased splenic colonisation between 7 and 21 days, and the lower challenge dose needed to achieve the same degree of colonisation as for CD-1 mice indicated that BALB/c mice were more sensitive to brucella infection. This could also explain the observation that anti-OMP MAbs did not decrease splenic colonisation in BALB/c mice. Passively administered anti-LPS MAbs could decrease brucella infection in mice, as observed on days 7 and 21 after challenge with anti-LPS MAb, by the opsonisation of bacteria during the first hours of the infection. At that time, the possible antiimmunoglobulin response against MAbs is not yet developed and the possible influence of the strain would be minimised. Short-term protection produced by passive immunisation with MAbs in the mouse model is only one aspect of the immune mechanisms which operate against Brucella spp. Cellular immunity probably interacts with humoral immunity. OMPs probably play a major role in cellular immunity and a minor role in humoral immunity. Their precise contribution will be evaluated by active immunisation with recombinant proteins.

We are grateful to J.-M. Verger and M. Grayon for supplying the B. abortus 544 virulent strain. A.C. was supported by the Institut National pour l'Encouragement de la Recherche Scientifique dans l'Industrie et l'Agriculture (IRSIA). This work was supported by CEC ECLAIR contract no. AGRE 0049.

\section{References}

1. Pavlov H, Hogarth M, McKenzie IFC, Cheers C. In vivo and in vitro effects of monoclonal antibody to Ly antigens on immunity to infection. Cell Immunol 1982; 71: 127-138.

2. Plommet $\mathbf{M}$, Plommet A-M. Immune serum-mediated effects on brucellosis evolution in mice. Infect Immun 1983; 41 : 97-105.

3. Plommet M, Plommet A-M. Anti-Brucella cell-mediated immunity in mice vaccinated with a cell wall fraction. $A n n$ Rech Vet $1987 ; 18: 429-437$.

4. Mackaness GB. The immunological basis of acquired cellular resistance. J Exp Med 1964; 120: 105-120.

5. Cloeckaert A, Jacques I, Bosseray N et al. Protection conferred on mice by monoclonal antibodies directed against outermembrane-protein antigens of Brucella. $J$ Med Microbiol 1991; 34: 175-180.

6. Limet J, Plommet A-M, Dubray G, Plommet M. Immunity conferred upon mice by anti-LPS monoclonal antibodies in murine brucellosis. Ann Inst Pasteur Immunol 1987; 138: $417-424$.

7. Limet JN, Bosseray N, Garin-Bastuji B, Dubray G, Plommet $M$. Humoral immunity in mice mediated by monoclonal antibodies against the $\mathrm{A}$ and $\mathrm{M}$ antigens of Brucella.J Med Microbiol 1989; 30: 37-43.

8. Phillips M, Deyoe BL, Canning PC. Protection of mice against Brucella abortus infection by inoculation with monoclonal antibodies recognizing Brucella O-antigen. Am J Vet Res $1989 ; 50: 2158-2161$
9. Montaraz JA, Winter AJ, Hunter DM, Sowa BA, Wu AM, Adams LG. Protection against Brucella abortus in mice with O-polysaccharide-specific monoclonal antibodies. Infect Immun 1986; 51 : 961-963.

10. Alton GG, Jones LM, Angus RD, Verger JM. Techniques for the brucellosis laboratory. Paris, Institut National de la Recherche Agronomique. 1988: 34-42.

11. Plommet M, Bosseray N. Le contrôle des vaccins antibrucelliques par dénombrement des Brucella dans la rate de souris, vaccinées ou non, inoculées par voie intrapéritonéale. J Biol Stand 1977; 5: 261-274.

12. Bosseray N, Plommet A-M, Plommet M. Theoretical, practical and statistical basis for a general control method of activity for anti-Brucella vaccines. Dev Biol Stand 1984; 56: 257-270.

13. Bosseray N, Plommet $M$. Transformation normalisant la distribution du nombre de Brucella dans la rate de souris inoculées par voie intrapéritonéale. J Biol Stand 1976; 4 : 341-351.

14. Lison L. Statistique appliquée à la biologie expérimentale, la planification de l'expérience et l'analyse des résultats. Paris, Gauthier-Villars. 1968.

15. Svennerholm A-M, Wennerås C, Holmgren J, McConnell MM, Rowe B. Roles of different coli surface antigens of colonization factor antigen II in colonization by and protective immunogenecity of enterotoxigenic Escherichia coli in rabbits. Infect Immun 1990; 58: 341-346. 